\title{
Ozonation of quinoa seeds (Chenopodium quinoa Willd.): saturation and decomposition kinetics of ozone and physiological quality of seeds
}

\section{Ozonização de sementes de quinoa (Chenopodium quinoa Willd.): saturação e cinética de decomposição do ozônio e qualidade fisiológica das sementes}

\author{
Ernandes Rodrigues de Alencar ${ }^{1 *}$; Wilson Anchico Jojoa ${ }^{2} ;$ Karine Noronha Silva ${ }^{3}$; \\ Nara Oliveira Silva Souza ${ }^{1}$
}

\section{Highlights}

The first-order kinetic model was suitable for the porous medium of quinoa.

The half-life of ozone in the porous medium with quinoa was $6.08 \mathrm{~min}$ at $25^{\circ} \mathrm{C}$.

The quality of quinoa seeds was not affected by ozone at 885 ppm for $120 \mathrm{~min}$.

\begin{abstract}
Ozonation has been evaluated as an alternative method for seed treatment. In this context, the goal of this study was to evaluate the saturation process and kinetics of decomposition of ozone in a porous medium composed of quinoa BRS Syetetuba and possible changes in seed quality. Ozone concentration and saturation time in the porous medium and half-life were determined by adopting an inlet ozone concentration of $885 \mathrm{ppm}$ and a flow rate of $5.0 \mathrm{~L} \mathrm{~min}^{-1}$ at $25^{\circ} \mathrm{C}$. The ozonation periods adopted were $0,30,60,90$, and 120 min. Regarding the physiological quality of the seeds, the germination percentage, germination speed index, electrical conductivity, and length of the shoot, root, and normal seedlings were analyzed. At the inlet ozone concentration of $885 \mathrm{ppm}$ and a flow rate of $5.0 \mathrm{~L} \mathrm{~min}^{-1}$, the saturation concentration and saturation time in the porous medium composed of quinoa were $522.5 \mathrm{ppm}$ and $12.0 \mathrm{~min}$, respectively. The half-life of ozone in the porous medium was $6.08 \mathrm{~min}$ at $25^{\circ} \mathrm{C}$. Under these conditions, ozonation did not affect the physiological quality of quinoa BRS Syetetuba seeds for up to $120 \mathrm{~min}$.
\end{abstract}

Key words: Germination. Half-life. Saturation concentration. Saturation time. Seed treatment.

1 Associate Professor, Postgraduate Program in Agronomy, Faculty of Agronomy and Veterinary Medicine, University of Brasília, UnB, Brasília, DF, Brazil. E-mail: ernandesalencar@unb.br; narasouza@unb.br

2 Doctoral Student of the Postgraduate Program in Agronomy, Faculty of Agronomy and Veterinary Medicine, UnB, Brasília, DF, Brazil. E-mail: anchico20@hotmail.com

${ }^{3}$ Master's Student of the Postgraduate Program in Agronomy, Faculty of Agronomy and Veterinary Medicine, UnB, Brasília, DF, Brazil. E-mail: karinenoronha18@gmail.com

* Author for correspondence

Received: July 28, 2020 - Approved: Dec. 28, 2020 


\section{Resumo}

A ozonização tem sido avaliada como método alternativo para tratamento de sementes. Nesse contexto, objetivou-se avaliar o processo de saturação e a cinética de decomposição do ozônio em meio poroso composto de quinoa, cv. BRS Syetetuba, e possíveis alterações na qualidade das sementes. Determinaramse a concentração e o tempo de saturação do ozônio no meio poroso e a meia-vida, adotando-se concentração de entrada de 885 ppm, vazão de $5,0 \mathrm{~L} \mathrm{~min}^{-1}$, a $25^{\circ} \mathrm{C}$. Os períodos de ozonização adotados foram 0, 30, 60, 90 e 120 min. Quanto à qualidade fisiológica das sementes, analisaram-se o percentual de germinação, índice de velocidade de germinação, condutividade elétrica e comprimentos da parte aérea, do sistema radicular e das plântulas normais. Para concentração de entrada do ozônio de 885 ppm e vazão de 5,0 L min-1 a concentração e o tempo de saturação do ozônio no meio poroso composto de quinoa foi de 522,5 ppm e 12,0 min, respectivamente. A meia-vida do ozônio em meio poroso foi de 6,08 min, a $25^{\circ} \mathrm{C}$. Nas condições a adotadas, a ozonização não afeta a qualidade fisiológica das sementes de quinoa, cv. BRS Syetetuba, por até $120 \mathrm{~min}$.

Palavras-chave: Concentração de saturação. Germinação. Meia-vida. Tempo de saturação. Tratamento de sementes.

\section{Introduction}

Quinoa (Chenopodium quinoa Willd.) is a herbaceous plant characterized by a tetraploid and halophytic culture (Angeli et al., 2020). This culture was domesticated by the inhabitants of the Andes Mountains thousands of years ago. It is distinguished by being a gluten-free pseudo-cereal with high-quality protein (Bazile, Jacobsen, \& Verniau, 2016). Präger, Munz, Nkebiwe, Mast and Graeff-Hönninger (2018) stated that in quinoa, essential amino acids represent 20 to $30 \%$ of crude protein and approximately $60 \%$ of fatty acids is linoleic acid. Within this context, quinoa represents an excellent alternative for diversification in agriculture and to guarantee food security because of the growing demand for food by the world population (Ruiz et al., 2014).

Faced with the need to produce increasingly more food because of the growing world demand, it is essential to use quality seeds, considering physical, genetic, and sanitary aspects. Ozone has been indicated as an antimicrobial agent owing to its high oxidative potential, which is equal to 2.07 $\mathrm{mV}$ (Guzel-Seydim, Greene, \& Seydim, 2004), with proven action for the control of bacteria, viruses, and fungi (Kang et al., 2015; Rodrigues et al., 2015; Brito et al., 2018; Megahed, Aldridge, \& Lowe, 2018; S. M. O. Souza, Alencar, Ribeiro, \& Ferreira, 2019; Oliveira et al., 2020). It also has proven effective in controlling insects on stored grains (Sousa, Faroni, \& Guedes, 2017; Silva, Faroni, Sousa, Prates, \& Abreu, 2019).

In addition to ozone as an alternative to traditional methods of controlling microorganisms and storage pest insects, there are reports in the literature that indicate a positive effect of ozone on the physiological quality of seeds (Pandiselvam et al., 2020), including of corn (Zea mays L.) (Violleau, Hadjeba, Albet, Cazalis, \& Surel, 2008; Monteiro, Alencar, Souza, \& Leão, 2020) and tomatoes (Lycopersicon esculentum Mill.) (Sudhakar et al., 2011). In previous research regarding the physiological quality of the seeds, several 
variables were considered, such as germination percentage, germination speed index, length of the root and normal seedlings, and electrical conductivity (Violleau et al., 2008; Monteiro et al., 2020).

Among the main characteristics of ozone, its instability stands out with a halflife of $20 \mathrm{~min}$ at $20^{\circ} \mathrm{C}$, as it decomposes into oxygen (Novak \& Yuan, 2007). In contact with organic matter, such as grains and seeds, the decomposition process is accelerated, which makes it essential to conduct studies to verify the behavior of the gas in contact with different materials. Data are available in the literature regarding the saturation and decomposition of ozone in a porous medium containing different grains, such as of corn (Zea mays L.) (J. V. S. Souza, Alencar, Junqueira, \& Oliveira, 2018; Silva et al., 2019), peanuts (Arachis hypogaea L.) (Alencar, Faroni, Martins, Costa, \& Cecon, 2011), and rice (Oryza sativa L.) (Pandiselvam, Venkatachalam, \& Rajamani, 2015; Santos, Faroni, Cecon, Ferreira, \& Pereira, 2016).

Parameters, such as saturation concentration, saturation time, and half-life, are essential for assessing the technical viability and dimensioning of ozonation systems (Alencar et al., 2011). It is noteworthy that it is essential to study the behavior of the gas in the porous medium, given its rapid degradation when in contact with organic matter. Rapid ozone decomposition means lower gas saturation concentration in the porous medium. There is also a need to assess the quality of the product subjected to ozonation, considering the high oxidative potential of the gas, especially when subjected to seeds, and possible undesirable changes when inappropriate gas concentrations are adopted. The indication of a combination between concentration and the period of exposure to the gas is essential, in such a way that it does not produce a reduction in the percentage of germination or the length of the root or an increase in electrical conductivity.

Consequently, the objectives of the present study were to evaluate the saturation process and kinetics of ozone decomposition in a porous medium composed of quinoa BRS Syetetuba and possible physiological quality changes in the seeds.

\section{Material and Methods}

In the present study, seeds of quinoa (Chenopodium quinoa Willd.) BRS Syetetuba, with $10 \%$ moisture content (wet basis, w.b.), were used. In the first stage of the study, the saturation process and kinetics of decomposition of ozone in a porous medium composed of quinoa seeds were evaluated. In the second stage, the physiological quality of the quinoa seeds subjected to ozonation was analyzed.

Saturation process and decomposition kinetics of ozone

For the evaluation of the ozone saturation and decomposition processes, three $1.0 \mathrm{~kg}$ quinoa seed samples were placed in 3.0-L glass containers with lids, with connections for the inlet and the outlet of the gas. Ozone was produced by a generator with an oxygen concentrator attached (Model O\&L 3.0 RM, Ozone \& Life, São José dos Campos, SP, Brazil), based on the Dielectric Barrier Discharge method.

Initially, ozone was injected at an inlet ozone concentration of $885 \mathrm{ppm}\left(\mathrm{C}_{0}\right)$ and a flow rate of $5.0 \mathrm{~L} \mathrm{~min}^{-1}$ at $25^{\circ} \mathrm{C}$. The ozone 
concentration at the outlet of the system was quantified every $2.5 \mathrm{~min}$, up to $10 \mathrm{~min}$, and thereafter, every $5 \mathrm{~min}$, until the gas concentration remained constant (Alencar et al., 2011). The ozone concentration was determined by the iodometric method, according to Clescerl, Greenberg and Eaton (2000). From the results obtained, it was possible to relate the residual concentration of ozone with the ozonation period, using the sigmoidal equation (Equation 1). From the coefficients $b$ and $c$ of Equation 1, saturation time was obtained (Equation 2), according to Venegas, Harris and Simon (1998). Knowing the saturation time $\left(\mathrm{t}_{\mathrm{Sat}}\right)$, the saturation concentration $\left(\mathrm{C}_{\mathrm{Sat}}\right)$ was calculated.

$$
\begin{array}{ll}
\mathrm{C}=\left[\frac{\mathrm{a}}{1+\mathrm{e}^{-\left(\frac{\mathrm{t}-\mathrm{b}}{\mathrm{c}}\right)}}\right] & \text { Equation 1 } \\
\mathrm{t}_{\mathrm{Sat}}=\mathrm{b}+2 \mathrm{c} & \text { Equation 2 }
\end{array}
$$

where, C ozone concentration (ppm), $t$ the ozonation period ( $\min )$, and $a, b$, and $c$ constants in the equations.
The decomposition of ozone after the saturation process of the porous medium was evaluated by determining the decomposition rate constant, as described by Alencar et al. (2011). The residual ozone concentration was quantified after intervals of time when the injection was interrupted and during which the gas decomposition occurred. This procedure was conducted until it was not possible to quantify residual ozone by the iodometric method.

The kinetic models of zero order, first order, and second order were adjusted to the residual ozone concentration data as a function of the different times. The decomposition kinetics models, their integrated and linearized equations, and half-lives are shown in Table 1 (Wright, 2004), where $k$ is the decomposition rate constant. Adjustments of the decomposition kinetics models after linearization were performed by regression analysis.

Table 1

Models of decomposition kinetics and respective integrated and linearized equations and half-lives
Order Differential equation Integrated and Linearized Equation Half-life
0 $\frac{\mathrm{dC}}{\mathrm{dt}}=-\mathrm{k}$ $\mathrm{C}=\mathrm{C}_{0}-\mathrm{kt}$ $\mathrm{t}_{1 / 2}=\frac{\mathrm{C}_{0}}{2 \mathrm{k}}$
1 $\frac{\mathrm{dC}}{\mathrm{dt}}=-\mathrm{kC}$ $\ln \mathrm{C}=\ln \mathrm{C}_{0}-\mathrm{kt}$ $\mathrm{t}_{1 / 2}=\frac{\ln (2)}{\mathrm{k}}$
2
$\frac{\mathrm{dC}}{\mathrm{dt}}=-\mathrm{kC}^{2}$
$\frac{1}{\mathrm{C}}=\frac{1}{\mathrm{C}_{0}}+\mathrm{kt}$
$\mathrm{t}_{1 / 2}=\frac{1}{\mathrm{kC}_{0}}$

Source: Wright (2004). 
Physiological quality of ozonated quinoa seeds

Regarding the physiological quality of quinoa seeds, samples were subjected to ozonation at an inlet ozone concentration of $885 \mathrm{ppm}$, flow rate of $5.0 \mathrm{~L} \mathrm{~min}^{-1}$, and temperature of $25^{\circ} \mathrm{C}$. The ozonation periods adopted were $0,30,60,90$, and $120 \mathrm{~min}$, with three repetitions each containing 100 $g$ of seeds. The quality of quinoa seeds was analyzed by considering the following variables: germination percentage, germination speed index, electrical conductivity, and lengths of normal seedlings, shoots, and roots.

Germination ( $G$, \%): For each repetition referring to the different ozonation periods, 50 seeds were sown on two sheets of germitest paper, previously moistened with distilled water at an amount equivalent to three times the dry weight of the paper, placed inside plastic boxes of the gerbox type $(11 \times 11$ $\times 3 \mathrm{~cm})$, according to F. F. J. Souza, Souza, Souza, Spehar and Jesus (2017). The gerbox boxes were maintained at $25{ }^{\circ} \mathrm{C}$ in a BODtype climatic chamber, with continuous light, and normal seedlings were quantified on the fourth day. For quinoa seeds, F. F. J. Souza et al. (2017) recommended counting at the end of the fourth day of the germination test. The results were expressed as percentages.

Germination speed index (GSI): The GSI was determined from the daily count of normal seedlings during the germination test. Equation 3 was used to calculate GSI (Maguire, 1962).

$$
\mathrm{GSI}=\left(\frac{G_{1}}{\mathrm{~N}_{1}}\right)+\left(\frac{G_{2}}{\mathrm{~N}_{2}}\right)+\ldots\left(\frac{G_{\mathrm{n}}}{\mathrm{N}_{\mathrm{n}}}\right) \quad \text { Equation } 3
$$

where, $G$ is the number of normal plants observed (from the first to the last count), and
$\mathrm{N}$ is the number of days (from the first to the last count).

Electrical conductivity: The methodology described by Vieira and Krzyzanowski (1999) was adopted, with modifications. For each repetition, 50 seeds were weighed and placed in $200-\mathrm{mL}$ containers, with $50 \mathrm{~mL}$ of deionized water, and maintained at $25^{\circ} \mathrm{C}$ for 6 h. F. F. J. Souza, Spehar, Souza, Souza and Cajamarca (2015) defined the 6-h interval as suitable for the electrical conductivity test for quinoa. Then, the electrical conductivity of the solution was measured using a Tec-4MP digital conductivity meter (Tecnal, Piracicaba, SP, Brazil). The results were expressed in $\mu S \mathrm{~cm}^{-1} \mathrm{~g}^{-1}$.

Normal seedling (NSL, $\mathrm{cm}$ ), shoot $(S L, c m)$, and root $(R L, c m)$ lengths: For each repetition, NSL, SL, and RL of 10 normal seedlings were measured with a ruler in millimeters.

\section{Statistical analysis}

A completely randomized design was adopted, with three replications of 1.0 $\mathrm{kg}$ samples for the ozone decomposition kinetics and $100 \mathrm{~g}$ for the test regarding the effects of ozone on the physiological quality of quinoa seeds. Regression analysis was used for the processes of ozone saturation and decomposition in the porous medium, using SigmaPlot software version 10.0. To assess the physiological quality of quinoa seeds, an analysis of variance was initially performed, followed by Tukey's test at $5 \%$ probability, using StatPlus 5.0 software. 


\section{Results and Discussion}

Ozone saturation process and decomposition kinetics

The ozone saturation process in a porous medium composed of quinoa at the inlet ozone concentration of $885 \mathrm{ppm}$ at 25 ${ }^{\circ} \mathrm{C}$ is shown in Table 2 and Figure $1 \mathrm{~A}$. The sigmoidal equation proposed in the present study adequately adjusted to the residual ozone concentration data as a function of the ozonation period for quinoa seeds, with a determination coefficient $\left(R^{2}\right)$ of 0.96 . This type of equation has been used by others, who obtained satisfactory results for peanuts (Alencar et al., 2011), common corn and sweet corn (J. V. S. Souza et al., 2018), popcorn (Silva et al., 2019), and Brazil nuts (Oliveira et al., 2020).

Table 2

Adjusted regression equation for residual ozone concentration in the porous medium composed of quinoa (Chenopodium quinoa Willd.) seeds as a function of the ozonation period $(x)$ and respective determination coefficient $\left(R^{2}\right)$, saturation time $\left(t_{\text {sat' }}, \min \right)$, saturation concentration $\left(C_{\text {Sat }^{\prime}}\right.$ ppm), and relation between CSat and inlet ozone concentration $\left(C_{0}, 885 \mathrm{ppm}\right)$, for flow rate of $5.0 \mathrm{~L} \mathrm{~min}^{-1}$, at $25^{\circ} \mathrm{C}$
Adjusted regression
$\mathrm{R}^{2}$
$\mathrm{t}_{\mathrm{Sat}}(\mathrm{min})$
$\mathrm{C}_{\mathrm{Sat}}(\mathrm{ppm})$
$\mathrm{C}_{\mathrm{Sat}} / \mathrm{C}_{0}$
$\hat{y}=\frac{587.982}{1+\mathrm{e}^{-\left(\frac{\mathrm{x}-4.631}{3.679}\right)}}$
0.96
12.0
522.5
0.59

In the present study, a saturation time of $12.0 \mathrm{~min}$ was obtained for a saturation concentration of $522.5 \mathrm{ppm}$. The observed behavior of the saturation concentration in a porous medium composed of quinoa is in agreement with that described by other authors, who analyzed different types of grains. It is noteworthy that ozone initially reacts with active sites present on the surfaces of the materials, eliminating them (Mendez, Maier, Mason, \& Woloshuk, 2002). Additionally, according to these authors, after the elimination of the active sites on the surfaces of the grains, there was a reduction in ozone degradation and, consequently, an increase in the residual concentration.
Data referring to ozone saturation in porous media for different grains are found in the literature. J. V. S. Souza et al. (2018) ozonized different corn varieties, including common corn and sweet corn, and obtained saturation times between 6.5 and $164 \mathrm{~min}$. These authors indicated the possibility that physical properties may influence the saturation process of the porous medium, in addition to the chemical composition of the grains. Longer saturation times were obtained for sweet corn kernels, which showed high values of porosity, sphericity, and circularity in comparison with common corn. In peanuts, with relatively high lipid content, Alencar et al. (2011) verified saturation times between 173 and 192 
min; for quinoa, saturation time was lower. It is noteworthy that, unlike peanuts, quinoa has a high starch content, which according to $\mathrm{Wu}$, Morris and Murphy (2017) is higher than 50\%

A

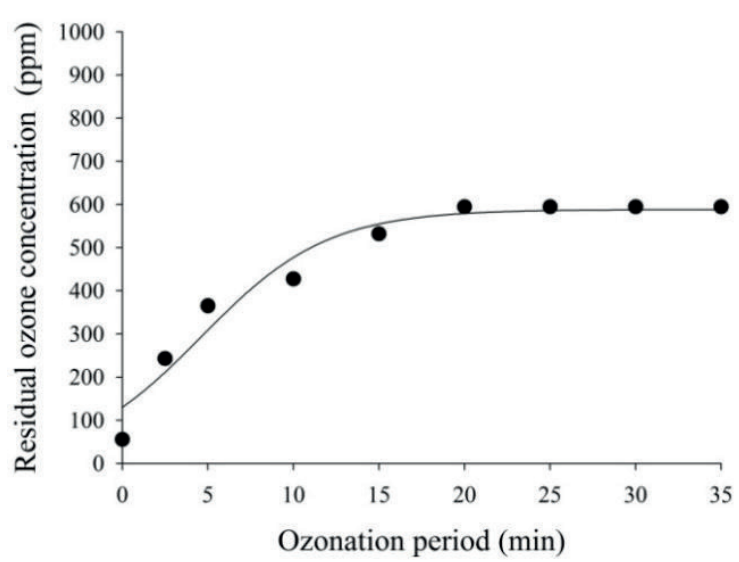

on a dry basis, corroborating the results of Santos et al. (2016) for rice seeds, in which also starch is the most abundant constituent (Bao, 2019), and the saturation time was $13.97 \mathrm{~min}$.

B

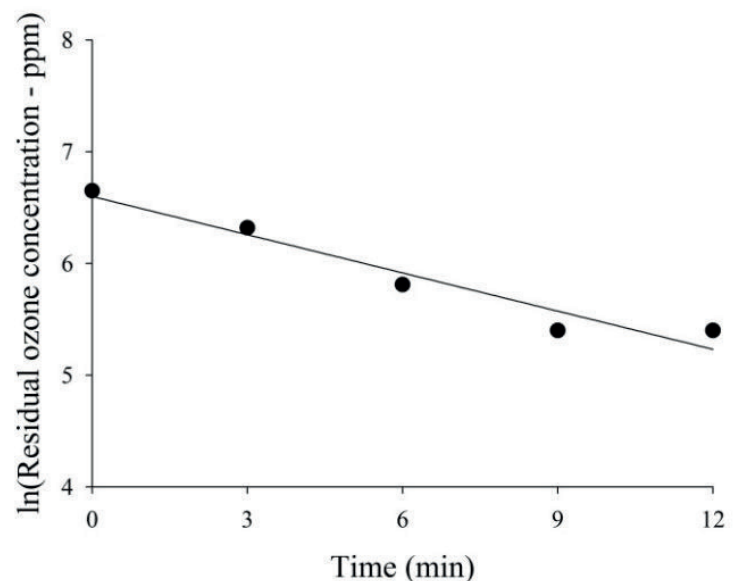

Figure 1. Curves of saturation (A) and decomposition $(B)$ of ozone in the porous medium composed of quinoa (Chenopodium quinoa Willd.) seeds, for inlet ozone concentration of 885 ppm and flow rate of $5.0 \mathrm{~L} \mathrm{~min}^{-1}$, at $25^{\circ} \mathrm{C}$.

The inlet ozone concentration adopted affects the time of ozone saturation in the porous medium (Oliveira et al., 2020). According to these authors, as the concentration of ozone increases, there is an exponential reduction in the saturation time for Brazil nuts. It is also important to highlight the value obtained for the relation between the saturation concentration and the inlet concentration $\left(\mathrm{C}_{\mathrm{Sat}} / \mathrm{C}_{0}\right)$, which was 0.59. It can be inferred that the higher the $\mathrm{C}_{\mathrm{Sat}} /$ $\mathrm{C}_{0}$, the less reactive is the porous medium in reference to the ozone gas. Roberto, Alencar Ferreira, Mendonça and Alves (2016) obtained $\mathrm{C}_{\mathrm{Sat}} / \mathrm{C}_{0}$ values between 0.32 and 0.48 for peanuts, considering different heights of the grain column and an ozone concentration of $1.59 \mathrm{mg} \mathrm{L}^{-1}$ ( $\approx 42.5 \mathrm{ppm}$ ).
Regarding the decomposition of ozone in the porous medium, the first-order model was the one that best fit the data of residual concentration as a function of time (Table 3 and Figure 1B). This result is in agreement with other authors who evaluated kinetic models in studies of ozone decomposition in porous media composed of grains (Alencar et al., 2011; Pandiselvam et al., 2015; Silva et al., 2019). Considering the first-order kinetic model, the half-life of ozone in the porous medium composed of quinoa was $6.08 \mathrm{~min}$ at $25^{\circ} \mathrm{C}$. The half-life of ozone for quinoa was lower than that obtained by Alencar et al. (2011), who analyzed peanuts (moisture content of $7.1 \%$ w.b. $/ 25^{\circ} \mathrm{C}$ ) and obtained a half-life of $7.70 \mathrm{~min}$ at $25^{\circ} \mathrm{C}$, and by J. V. S. Souza et al. (2018) for common corn 
(moisture content of $13.0 \%$ w.b. $/ 25^{\circ} \mathrm{C}$ ), with a half-life of $10.50 \mathrm{~min}$. On the other hand, the half-life of ozone in quinoa medium was similar to the values obtained by Silva et al. (2019) for popcorn, with $11.2 \%$ moisture content (w.b.).

Table 3

Kinetic models of ozone decomposition in the porous medium composed of quinoa (Chenopodium quinoa Willd.) seeds and their respective half-lives, at $25^{\circ} \mathrm{C}$

\begin{tabular}{cccc}
\hline Order & Adjusted regression & R2 & Half-life (min) \\
\hline 0 & $\hat{y}=-47.8970^{*} x+708.3423$ & 0.90 & 8.06 \\
1 & $\hat{y}=-0.1140^{* *} x+6.6000$ & 0.94 & 6.08 \\
2 & $\hat{y}=0.0003^{* *} x+0.0012$ & 0.92 & 4.31 \\
\hline
\end{tabular}

* Significant $(p<0.05)$

** Significant $(p<0.01)$.

Similar to the saturation process, the decomposition of ozone in the porous medium may be influenced by the physical properties and chemical composition of the ozonated material (J. V. S. Souza et al., 2018). Regarding the effects of the chemical composition, Oliveira et al. (2020) inferred that the product's high lipid content favors the decomposition of ozone in the porous medium. Another variable of the chemical composition that influences the decomposition of ozone in the porous medium is the humidity of the product. According to Pandiselvam et al. (2015), as the moisture content of the product increases, the ozone half-life in the porous medium is reduced. It is noteworthy that other factors influence the decomposition of this gas, such as temperature. As the temperature rises, ozone decomposition is accelerated (Alencar et al., 2011).
Physiological quality of ozonated quinoa seeds

Regarding the physiological quality of quinoa seeds subjected to ozonation at an inlet concentration of 885 ppm for up to 120 min, there was no significant variation $(p>$ 0.05) due to different ozonation times, when analyzing the germination, GSI, electrical conductivity, NSL, SL, and RL (Figures 2 and 3). The germination percentage varied between $74.3 \%$ and $81.4 \%$ (Figure $2 \mathrm{~A}$ ), whereas the GSI remained between 25.0 and 27.2 (Figure 2B). Concerning electrical conductivity, the average values remained in the range of 305.2$339.8 \mu \mathrm{S} \mathrm{cm}^{-1} \mathrm{~g}^{-1}$ (Figure 2C). Freitas, Faroni, Lopes, Heleno and Prates (2017) also failed to observe significant variation in electrical conductivity for ozonized corn at an ozone concentration of $0.86 \mathrm{mg} \mathrm{L}^{-1}$ for up to $60 \mathrm{~min}$. Regarding the mean values of NSL (Figure 3A), $\mathrm{SL}$ (Figure $3 \mathrm{~B}$ ), and $\mathrm{RL}$ (Figure $3 \mathrm{C}$ ), the variation remained between 7.8 and $10.5 \mathrm{~cm}, 3.4$ and 4.7 $\mathrm{cm}$, and 4.4 and $5.9 \mathrm{~cm}$, respectively. 
A

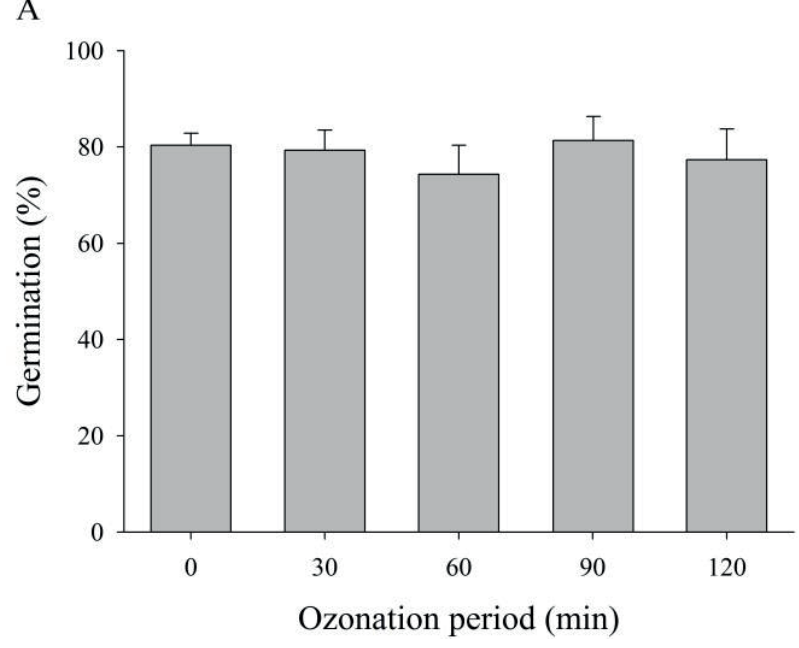

$\mathrm{C}$
B

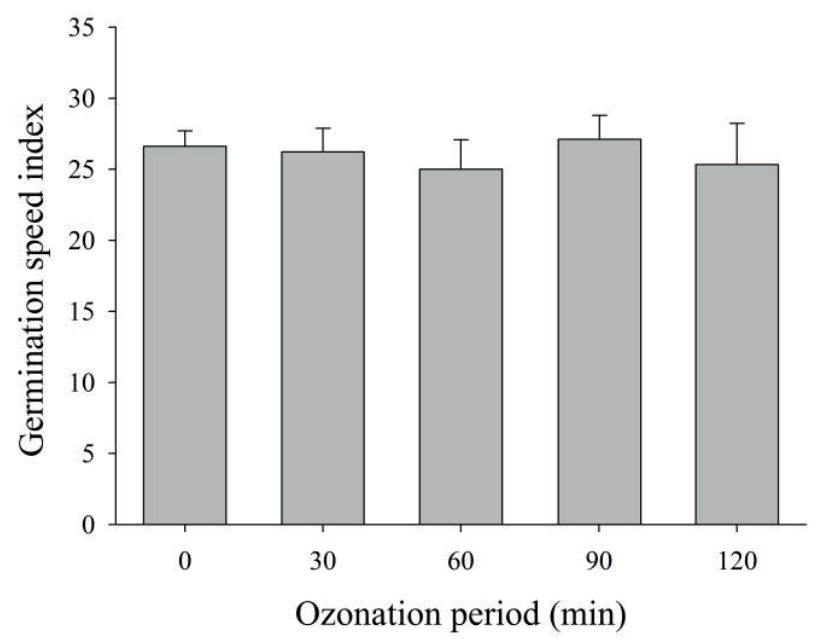

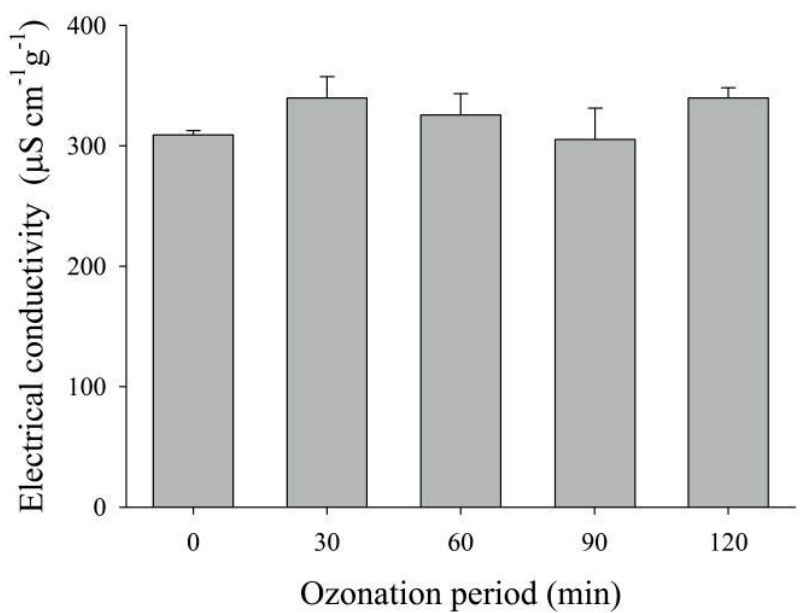

Figure 2. Germination $(\%, A)$, germination speed index $(\mathrm{GSI}, \mathrm{B})$, and electrical conductivity $\left(\mu \mathrm{S} \mathrm{cm}{ }^{-1}\right.$ $\mathrm{g}^{-1}$, C) of quinoa (Chenopodium quinoa Willd.) seeds ozonated at an inlet ozone concentration of $885 \mathrm{ppm}$, for up to $120 \mathrm{~min}$, at $25^{\circ} \mathrm{C}$. 
A

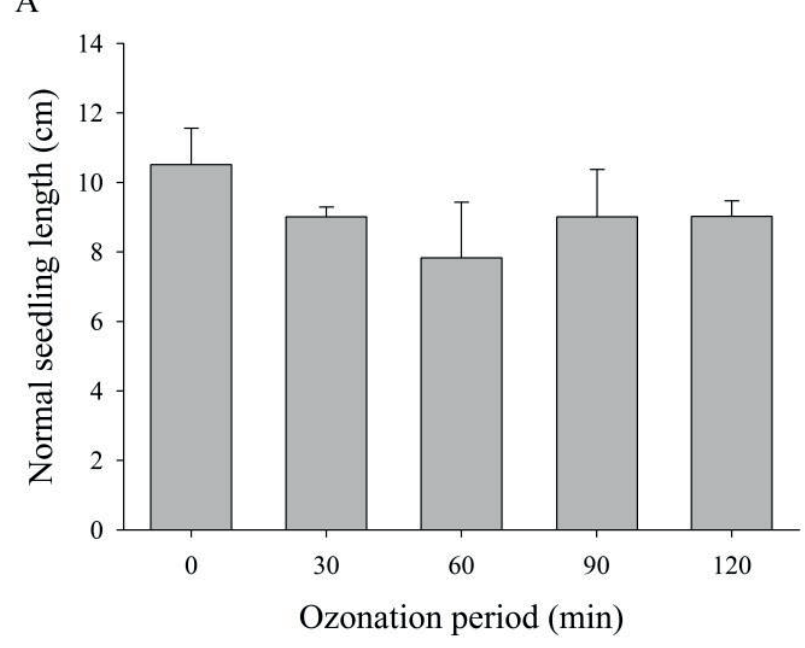

$\mathrm{C}$
B

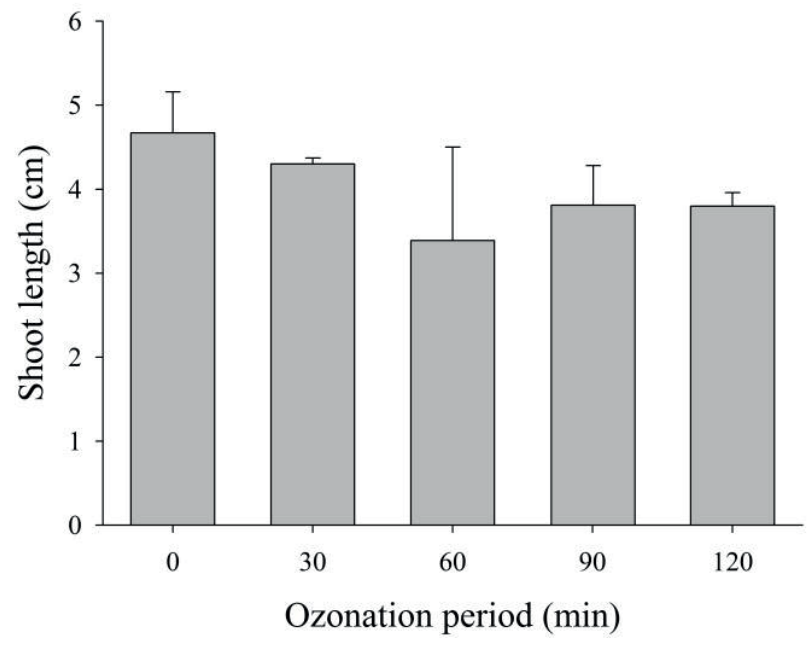

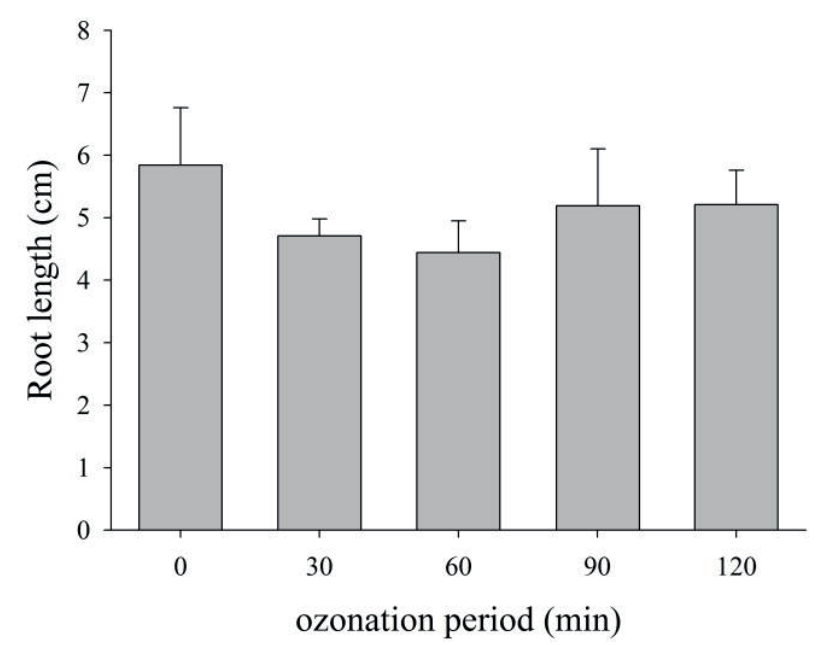

Figure 3. Normal seedling (NSL, cm, A), shoot $(S L, c m, B)$, and root $(R L, c m, C)$ lengths referring to quinoa (Chenopodium quinoa Willd) seeds ozonated at an inlet ozone concentration of 885 ppm, for up to $120 \mathrm{~min}$, at $25^{\circ} \mathrm{C}$.

However, it is noteworthy that there are reports in the literature that indicate a positive effect of ozonation on corn seeds (Violleau et al., 2008; Maximiano, Carmona, Souza, Alencar, \& Blum, 2018) and tomatoes (Sudhakar et al., 2011). Violleau et al. (2008) observed a positive effect of ozone gas on germination and root length when they analyzed ozonized corn seeds, at an ozone concentration of $20 \mathrm{mg} \mathrm{L}^{-1}$
( $\approx 9.340 \mathrm{ppm}$ ) for periods of 6.8 and $20.5 \mathrm{~min}$. These authors associated the positive effects observed to the oxidative stress caused in corn seeds when they were treated with high gas concentration at relatively short exposure time. It is important to highlight that in the present study, the gas inlet concentration was lower than that used by Violleau et al. (2008), which certainly influenced the obtained 
results. Maximiano et al. (2018) found that ozone in aqueous media intensified the initial development of corn seedlings. Sudhakar et al. (2011) stated that ozone accelerated the germination and development of tomato seedlings, causing a reduction in the abscisic acid content in the seeds.

The importance of assessing the effects of ozone on the physiological quality of seeds was highlighted because this gas has a high oxidative potential (2.07 mV) (GuzelSeydim et al., 2004), which can impair the quality of the seeds. Thus, it was found that under the conditions adopted in the present study, ozone did not cause deterioration in quinoa seeds. Therefore, ozonation at an inlet concentration of up to $885 \mathrm{ppm}$ for $120 \mathrm{~min}$ can be used in future studies intended to verify the effects of ozone on the control of fungi or insects.

\section{Conclusion}

Saturation concentration and saturation time in a porous medium composed of quinoa BRS Syetetuba were equal to 522.5 ppm and $12.0 \mathrm{~min}$, respectively, with a half-life of $6.08 \mathrm{~min}$, at $25{ }^{\circ} \mathrm{C}$. Ozonation at an inlet concentration of $885 \mathrm{ppm}$, for up to 120 min, did not alter the physiological quality of quinoa seeds.

\section{Acknowledgments}

Thanks to the Coordination for the Improvement of Higher Education Personnel (CAPES), to the scholarship (Finance Code 001), and the Dean of Research and Innovation at the University of Brasília.

\section{References}

Alencar, E. R., Faroni, L. R. D., Martins, M. A., Costa, A. R., \& Cecon, P. R. (2011). Decomposition kinetics of gaseous ozone in peanuts. Engenharia Agrícola, 11(2), 930-939. doi: 10.16194/j.cnki.31-1059/ g4.2011.07.016

Angeli, V., Silva, P. M., Massuela, D. C., Khan, M. W., Hamar, A., Khajehei, F.,... Piatti, C. (2020). Quinoa (Chenopodium quinoa Willd.): an overview of the potentials of the "Golden Grain" and socio-economic and environmental aspects of Its cultivation and marketization. Foods, 9(2), 1-31. doi: $10.3390 /$ foods 9020216

Bao, J. (2019). 3 - Rice starch. In J. Bao (Ed.), Rice - chemistry and technology (4th ed., pp. 55-108). Cambridge: Woodhead Publishing.

Bazile, D., Jacobsen, S.-E., \& Verniau, A. (2016). The global expansion of quinoa: trends and limits. Frontiers in Plant Science, 7(5), 1-6. doi: 10.3389/fpls.2016.00622

Brito, J. G., Jr., Faroni, L. R. D., Cecon, P. R., Benevenuto, W. C. A. N., Benevuto Júnior, A. A., \& Heleno, F. F. (2018). Efficacy of ozone in the microbiological disinfection of maize grains. Brazilian Journal of Food Technology, 21, e2017022. doi: 10.1590/1981-6723.02217

Clescerl, L. S., Greenberg, A. E., \& Eaton, A. D. (2000). Standard methods for the examination of water and wastewater. Denver: Water Work Association.

Freitas, R. S., Faroni, L. R. D., Lopes, M. E. L., Heleno, F. F., \& Prates, L. H. F. (2017). Degradation kinetics of pirimiphos-methyl residues in maize grains exposed to ozone 
gas. Journal of Stored Products Research, 74, 1-5. doi: 10.1016/j.jspr.2017.08.008

Guzel-Seydim, Z. B., Greene, A. K., \& Seydim, A. C. (2004). Use of ozone in the food industry. LWT - Food Science and Technology, 37(4), 453-460. doi: 10.1016/j.Iwt.2003.10.014

Kang, M. H., Pengkit, A., Choi, K., Jeon, S. S., Choi, H. W., Shin, D. B.,.. Park, G. (2015). Differential inactivation of fungal spores in water and on seeds by ozone and arc discharge plasma. Plos One, 10(9), 1-16. doi: 10.1371/journal.pone.0139263

Maguire, J. D. (1962). Speed of germination aid in selection and evaluation for seedling emergence and vigor. Crop Science, 2(2), 176-177. doi: 10.2135/cropsci1962.0011 183X000200020033x

Maximiano, C. V., Carmona, R., Souza, N. O. S., Alencar, E. R., \& Blum, L. E. B. (2018). Physiological and sanitary quality of maize seeds preconditioned in ozonated water de milho pré-condicionadas em água ozonizada. Revista Brasileira de Engenharia Agrícola e Ambiental, 22(5), 360-365. doi: 10.1590/1807-1929/ agriambi.v22n5p360-365

Megahed, A., Aldridge, B., \& Lowe, J. (2018). The microbial killing capacity of aqueous and gaseous ozone on different surfaces contaminated with dairy cattle manure. Plos One, 13(5), 1-22. doi: 10.1371/journal. pone.0196555

Mendez, F., Maier, D. E., Mason, L. J., \&Woloshuk, C. P. (2002). Penetration of ozone into columns of stored grains and effects on chemical composition and processing performance. Journal of Stored Products Research, 39(1), 33-44. doi: 10.1016/ S0022-474X(02)00015-2
Monteiro, N. O. C., Alencar, E. R., Souza, N. O. S., \& Leão, T. P. (2020). Ozonized water in the preconditioning of corn seeds: physiologicalqualityandfieldperformance. Ozone: Science \& Engineering, 1-15. doi: 10.1080/01919512.2020.1836472

Novak, J. S., \& Yuan, J. T. C. (2007). The ozonation concept: advantages of ozone treatment and commercial developments. In G. Tewari, \& V. K. Juneja (Eds.), Advances in Thermal and Non-Thermal Food Preservation (pp. 185-193). Ames: Blackwell Publishing.

Oliveira, J. M., Alencar, E. R., Blum, L. E. B., Ferreira, W. F. S., Botelho, S. C. C., Racanicci, A. M. C.,... Silva, C. R. (2020). Ozonation of Brazil nuts: decomposition kinetics, control of Aspergillus flavus and the effect on color and on raw oil quality. LWT- Food Science and Technology, 123, 109106. doi: 10. 1016/j.Iwt.2020.109106

Pandiselvam, R., Mayookha, V. P., Kothakota, A., Sharmila, L., Ramesh, S. V., Bharathi, C. P.,... Srikanth, V. (2020). Impact of ozone treatment on seed germination - a systematic review. Ozone: Science and Engineering, 42(4), 331-346. doi: 10.1080/01919512.2019.1673697

Pandiselvam, R., Venkatachalam, T., \& Rajamani, M. (2015). Decay rate kinetics of ozone gas in rice grains. Ozone: Science \& Engineering, 37(5), 450-455. doi: $10.1080 / 01919512.2015 .1040912$

Präger, A., Munz, S., Nkebiwe, P. M., Mast, B., \& Graeff-Hönninger, S. (2018). Yield and quality characteristics of different quinoa (Chenopodium quinoa willd.) cultivars grown under field conditions in southwestern Germany. Agronomy, 8(10), 1-19. doi: 10.3390/agronomy8100197 
Roberto, M. A., Alencar, E. R., Ferreira, W. F. S., Mendonça, M., \& Alves, H. (2016). Saturação do ozônio em coluna contendo grãos de amendoim e efeito na qualidade. Brazilian Journal of Food Technology, 19, e2015051. doi: 10.1590/1981-6723.5115

Rodrigues, V. O., Costa, F. R., Nery, M. C., Cruz, S. M., Melo, S. G. F. de, \& Carvalho, M. L. M. de. (2015). Treating sunflower seeds subjected to ozonization. Journal of Seed Science, 37(3), 202-210. doi: 10.1590/2317-1545v37n3148582

Ruiz, K. B., Biondi, S., Oses, R., AcuñaRodríguez, I. S., Antognoni, F., MartinezMosqueira, E. A.,... Molina-Montenegro, M. A. (2014). Quinoa biodiversity and sustainability for food security under climate change. A review. Agronomy for Sustainable Development, 34(2), 349-359. doi: 10.1007/s1359 3-013-0195-0

Santos, R. R., Faroni, L. R. D., Cecon, P. R., Ferreira, A. P. S., \& Pereira, O. L. (2016). Ozone as fungicide in rice grains. Revista Brasileira de Engenharia Agricola e Ambiental, 20(3), 230-235. doi: 10.1590/ 1807-1929/agriambi.v20n3p230-235

Silva, M. V. A., Faroni, L. R. A., Sousa, A. H., Prates, L. H. F., \& Abreu, A. O. (2019). Kinetics of the ozone gas reaction in popcorn kernels. Journal of Stored Products Research, 83, 168-175. doi: 10.1016/ j.jspr.2019.06.014

Sousa, A. H., Faroni, L. R. A., \& Guedes, R. N. C. (2017). Locomotor behavior of Sitophilus zeamais populations under sublethal ozone exposure. Journal of Pest Science, 90(1), 239-247. doi: 10.1007/s10340-0160738-7

Souza, F. F. J., Souza, J. E. A., Souza, N. O. S., Spehar, C. R., \& Jesus, T. F. (2017).
Standardizing germination tests for quinoa seeds. African Journal of Agricultural Research, 12(3), 155-160. doi: 10. 5897/ ajar2016.11820

Souza, F. F. J., Spehar, C. R., Souza, N. O. S., Souza, R. T. G., \& Cajamarca, S. M. N. (2015). Teste de condutividade elétrica em sementes de quinoa. Anais do Congresso Brasileiro de Sementes, Foz do Iguaçu, PR, Brasil, 19.

Souza, J. V. S., Alencar, E. R., Junqueira, A. M. R., \& Oliveira, G. P. (2018). Ozone saturation and decomposition kinetics in porous medium containing different hybrids of maize. Revista Brasileira de Engenharia Agrícola e Ambiental, 22(4), 286-291. doi: 10.1590/1807-1929/agriambi.v22n4 p286-291

Souza, S. M. O., Alencar, E. R., Ribeiro, J. L., \& Ferreira, M. A. (2019). Inactivation of Escherichia coli 0157:H7 by ozone in different substrates. Brazilian Journal of Microbiology, 50(1), 247-253. doi: 10. 1007/s42770-018-0025-2

Sudhakar, N., Nagendra-Prasad, D., Mohan, N., Hill, B., Gunasekaran, M., \& Murugesan, K. (2011). Assessing influence of ozone in tomato seed dormancy alleviation. American Journal of Plant Sciences, 2(3), 443-448. doi: 10.4236/ajps.2011.23051

Venegas, J. G., Harris, R. S., \& Simon, B. A. (1998). A comprehensive equation for the pulmonary pressure-volume curve. Journal of Applied Physiology, 84(1), 389395. doi: 10.1152/jappl.1998.84.1.389

Vieira, R. D., \& Krzyzanowski, F. C. (1999). Teste de condutividade elétrica. In R. D. Vieira, \& J. B. Françaneto (Eds.), Vigor de sementes: conceitos e testes (pp. 4.1-4.26). Londrina: ABRATES. 
Violleau, F., Hadjeba, K., Albet, J., Cazalis, R., \& Surel, O. (2008). Effect of oxidative treatment on corn seed germination kinetics. Ozone: Science and Engineering, 30(6), 418-422. doi: 10.1080/0191951080 2474631

Wright, M. R. (2004). An introduction to quemical kinects. New York: John Wiley \& Sons.
Wu, G., Morris, C. F., \& Murphy, K. M. (2017). Quinoa starch characteristics and their correlations with the texture profile analysis (tpa) of cooked quinoa. Journal of Food Science, 82(10), 2387-2395. doi: 10. $1111 / 1750-3841.13848$ 